- council in 1997, has been signed by 28 of the council's 40 member states. Five countries - Denmark, Greece, San Marino, Slovakia and Slovenia - have ratified it, and Spain will join them in January.

Germany and Britain are the only large European countries not to have signed. "I feel that Germany should not be the last to sign," says Catenhusen. "Otherwise we risk being excluded from the discussion process in Europe."

The Greens, at their last party conference, unanimously voted against the conven- Catenhusen: 'sign tion. They fear it European convention' could undermine

German standards, bringing them down to the levels of some neighbouring countries such as Belgium, where, for example, there are no laws on embryo research.

But some members, such as Jens Reich, a bioinformaticist at the MaxDelbrück Centre for Molecular Medicine in Berlin and the Greens' 1994 candidate for federal president, argue more pragmatically that, despite its weaknesses, the convention should be signed as it sets minimal standards throughout Europe.

Ludger Honnefelder, director of the Institute of Science and Ethics at the University of Bonn, is a member of the German delegation in the Council of Europe's steering committee on bioethics. He firmly believes that Germany's accession to the convention would "significantly increase its international influence".

Despite the dispute about a commission d'enquête, there is general agreement in Germany on the need for continuous bioethical advice and monitoring. Catenhusen suggests that a national ethics commission, similar to Britain's Nuffield Council on Bioethics, should be established.

Werner Lensing, the Christian Democrat spokesman on bioethics in the parliamentary committee on research, agrees that ad hoc expert panels, which are used by the Nuffield council, would be effective. Just such an advisory panel, on the ethical implications of predictive genetic testing and reproductive medicine, was set up last week by the federal health ministry.

But Knoche insists that only a commission d'enquête would have the political weight appropriate to the scope of the issues in question: "Such a body is indispensable. And we would certainly not use it as a blocking tool.” Quirin Schiermeier

\title{
Israel urged to set up labs to carry out military research
}

\section{Jerusalem}

Government laboratories should be set up in Israel to carry out defence research, according to a report on revitalizing the country's military industries. Weapons development and production, it adds, should be carried out by private companies, rather than government corporations as at present.

The report was drawn up by a defence ministry committee headed by reserve general Moshe Peled. It recommends that Israel Aircraft Industries (IAI), Israel Military Industries, and Raphael (the Armament Development Authority), an auxiliary unit of the defence ministry, should be privatized.

But it adds that the research underpinning weapons development should be performed by a new system of government research laboratories.

As the report is classified, Peled is refusing to comment on it. But Yossi Snir, the committee's coordinator, says a summary that appeared in the Israeli daily newspaper Ha'aretzlast week is "reliable".

In recent years, Israel's defence industries have been plagued by falling sales, labour disputes over forced redundancies, and a lack of technological innovation. According to Ha'aretz, one problem is the difficulty of attracting highly qualified young scientists.

"Since the 1990s [the trend] is for talented people to leave government research laboratories and move to the flourishing private high-tech industry," confirms Zehev Tadmor, former president of the Technion, Israel's institute of technology.

There has been a mixed reaction to the proposal to create government defence laboratories, which do not currently exist in Israel. "I'm not sure that we have to separate out basic research," says Moshe Arens, former defence minister and former IAI deputy director-general. Privatizing the industries would be sufficient to make them more attractive to young scientists, he suggests.

But physicist and former minister of science and technology Yuval Ne'eman says the establishment of such laboratories would be a positive development, not only for defence industries but for Israeli science in general.

"Since nearly all research is performed at the universities, a tradition has become established according to which the amount of research performed in the country is tied to [its] number of students," Ne'eman complains. Government laboratories of the kind that exist in the United States and Europe could break the link between higher education and research budgets, he says.

The Peled report also calls for a reversal of the long decline in government investment in basic research.

Haim Watzman

\section{Concern at cheap AIDS drug fears}

\section{Cape Town}

Officials of a US foundation that has raised \$1 million to prevent paediatric AIDS in Africa are expressing concern at a statement from the health ministers of Southern African countries raising questions about the use of the anti-retroviral agent AZT and the cheaper alternative nevirapine.

The California-based Elizabeth Glaser Paediatric Trust has earmarked \$1 million for paediatric AIDS prevention in Africa using nevirapine, which is less expensive than AZT and simpler to administer. A single dose to mothers at the onset of labour, and a single dose to the baby in its first three days of life, cost less than $\$ 4$ per treatment.

But this initiative could suffer as the result of a joint statement issued by the health ministers of South Africa, Botswana, Zambia, Namibia, Mozambique, Swaziland, Lesotho, Zimbabwe, Malawi, Tanzania, Angola and Rwanda at a meeting in Johannesburg this month held to discuss a coordinated response on HIV/AIDS.
The ministers acknowledged that administering either drug can approximately halve the numbers of HIV-positive children born to mothers who are HIV positive.

But they expressed "grave concern over possible side effects as a result of their toxicity and the potential development of resistance to these compounds". They felt it was necessary to research the effects of "unnecessary exposure of children and mothers to these drugs".

This action is understood to have been heavily influenced by the South African government's position (see Nature 402, 225; 1999). In South Africa, 22 per cent of women attending antenatal clinics, and seven per cent of new babies, are HIV infected.

Both AZT and the oral form of nevirapine are registered with South Africa's Medicines Control Council. But it is understood that the suspension form of nevirapine, which is administered to infants, has not yet been submitted to the council for registration. Michael Cherry 